\title{
THE LIFE QUALITY OF FAMILIES WITH A MEMBER WITH A MENTAL DISABILITY
}

\author{
Zdenka Kozakova \\ Institute of Special Education Studies at Faculty of Education of Palacky \\ University in Olomouc
}

\begin{abstract}
This paper focuses on the quality of life of a family taking care of a mentally disabled member. In order to be able to provide families taking care of a disabled member with high-quality special-education care and support, it is at first necessary to learn about their needs in as complex a way as possible. This paper presents a selected summary of the results of a survey carried out by means of a questionnaire and a standardized questionnaire SEIQoL, in order to compare the quality of life of parents taking care of a mentally disabled child/children and the quality of life of parents taking care of a child/children without mental disability, and thus to ascertain those areas that would be desirable for further focus in the future.
\end{abstract}

Keywords: family, mental disability, quality of life, questionnaire, standardized questionnaire SEIQOL.

\section{Introduction}

The quality of life of families taking care of a disabled child represents a topic that is currently catching increasing attention. There are efforts to learn, as complexly as possible, about the needs of the tending families so as to ensure that the support provided to these families reaches the highest possible quality.

In this paper, we will focus on parents taking care of a mentally disabled child and on the quality of their lives. Firstly, we will define the basic terms, then we will present a selected summary of the results of a survey aimed at comparing the quality of life of parents taking care of a mentally disabled child/children and the quality of life of parents taking care of a child/children without mental disability.

\section{Terminology definition in the field of quality of life}

The issue of quality of life employs the human mind from time immemorial. The available literature offers a number of definitions of quality of life. In the conceptualization of this term and especially in methodological issues, however, we do not find any consensus. (Kozáková, 2013)

Quality of life is rather a troublesome and wide term, which is difficult to grasp for its multidimensionality and complexity (Dušková, Svobodová in Dvořáková et. al., 2006). It includes both the external life conditions as well as the internal conditions of a human being. It is linked to understanding the meaning of human existence and of existence in itself. It investigates the materialistic, psychological, social, spiritual and other conditions for a healthy and happy human life (Dušková, Svobodová in Dvořáková et. al., 2006). 
The term quality of life is most often grounded in the broader definition of health: "that is to feel well from the physiological, mental (spiritual) and also social points of view" (Prokešová, 2008, p. 17). The World Health Organization defines quality of life as "the individual's perception of their position in life in the context of their culture and value system and in relation to their goals, anticipations, norms and worries" (Vad'urová, Mühlpachr, 2005, p. 11). It is a wide concept that is multifactorially influenced by the individual's physical and mental state, social relationships and personal creed in the context of their environment (Vad’urová, Mühlpachr, 2005).

By life satisfaction we mean the measure that includes both physiological, mental (spiritual) and also social dimensions. We can also include into it the attitudes, values and value orientations of an individual (Prokešová, 2008).

The concept of quality of life can be approached from two dimensions, namely subjective and objective. Nowadays, experts are much more siginificantly inclined towards the subjective evaluation of quality of life. It is perceived as crucial and determinative for an individual's life (Vad'urová, Mühlpachr, 2005). Quality of life can be viewed from different perspectives, be it the sociological, psychological perspective or the perspective of cultural anthropology, medicine, ecology or economy. There are a number of definitions, perspectives, specifications and influencing factors and there are dozens of organizations addressing these issues.

\section{Methodological basis of the research}

Within the research, the selected summary of results of which we would like to present in this paper, we focused on the quality of life of families with a mentally disabled member. The aim of the research was to ascertain whether the care imparted to a mentally disabled child (hereinafter MD child) influences the quality of life of the tending parents, and to compare the quality of life of parents taking care of a mentally disabled child/children with the quality of life of parents taking care of a child/children without mental disability. To assemble the relevant results, we used the means of a standardized questionnaire SEIQoL and the means of a questionnaire, which had been used in the research of stressful and resilient factors and tendencies in persons taking care of a person with a health disability (Michalík, Valenta in Titzl, 2008). The questionnaire used open-ended questions, semi-close-ended and close-ended questions, as well as scale questions. The research questionnaire was divided into four parts. The first part inquired about personal data of the respondents. The individual questions were adapted so that both parents taking care of a MD child as well as those of a child without MD would be able to answer them. The second part focused on the respondent and their psychosocial and economical characteristics and perspectives. The third part was oriented to the area of work competencies of a person taking care of a child with MD or wihout it. The fourth part consisted of the standardized questionnaire SEIQoL. The 
standardized questionnaire SEIQoL (Schedule for the Evaluation of Individual Quality of Life) is the most wide-spread method of establishing quality of life. "The basis for it is how the quality of life is defined by the questioned person, and how it is evaluated by that person him/herself. The basic data are the statements of the given person"(Křivohlavý, 2002, p. 172). The respondent is supposed to state five life goals which they consider to be the most important in the given situation. For each of the five stated life goals, the respondent is supposed to state its importance and their satisfaction with the given stimulus. The satisfaction is given in percentage, where $0 \%$ represents the lowest margin (the respondent is completely dissatisfied with the given goal) and $100 \%$ represents the highest margin (the respondent is completely satisfied with the given goal). Importance is also expressed in percentage; however, the total sum of importance of all five goals must not be higher than $100 \%$ (Křivohlavý, 2001).

For cooperation within the carried out research, various types of institutions were contacted - 5 so-called "special schools", 3 kindergartens, 2 day care centers, and 1 elementary school with established special classes; furthermore, families with a MD child were contacted with the help of the charity society Maltézská pomoc. Contact was in the form of letters addressed to the directors of the institutions.

Altogether, 342 questionnaires were circulated, out of which 112 were returned. Out of 192 questionnaires circulated to parents of MD children, 53 questionnaires were returned (27.6\%). Out of 150 questionnaires distributed to parents of children without MD, 59 questionnaires were returned (39.3\%). The examined set thus consisted of 53 parents of children with MD and 59 parents of children without MD.

\section{Presentation of and discussion on the results of the research}

Within the research, we first established the personal data regarding the respondents and their children. Out of the total number of 53 parents taking care of a child with MD, there were 38 mothers (71.7\%) and 15 fathers $(28.3 \%)$. Out of the total number of 59 parents taking care of a child without MD who took part in the research, there were 51 mothers $(86.4 \%)$ and 8 fathers $(13.6 \%)$. 43 parents $(81 \%)$ of children with MD live in a marriage, 4 parents $(7.6 \%)$ live on their own, $4(7.6 \%)$ live in a partnership and 2 parents $(3.8 \%)$ stated a different alternative which they did not futher specify. 46 parents $(78 \%)$ of children without MD live in a marriage, 9 parents $(15.2 \%)$ live in a partnership, 3 parents $(5.1 \%)$ live on their own and 1 parent $(1.7 \%)$ did not state any option. 26 parents (49.1\%) of children with MD live in a city, $26(49.1 \%)$ live in a village, $1(1.8 \%)$ did not answer the question. 16 parents $(27.1 \%)$ of children without MD live in a city, $42(71.2 \%)$ live in a village, $1(1.7 \%)$ did not answer the question. 19 parents (35.8\%) taking care of a child with MD are aged between 20 and 40 years, 26 parents $(49.1 \%)$ are aged between 40 and $60 ; 3$ 
parents (5.7\%) are aged between 60 and 80 and 5 parents $(9.4 \%)$ did not answer the question. 5 parents $(8.5 \%)$ of children without MD are aged under 20 years; 44 parents $(74.6 \%)$ are aged between 20 and 40; 7 parents $(11.9 \%)$ are aged between 40 and 60 and 2 parents (3.4\%) were aged between 60 and 80 years. The question was not answered by 1 parent $(1.7 \%)$. As far as education of the parents of children with MD is concerned, 3 parents $(5.6 \%)$ stated elementary education, 18 completed secondary education without the leaving exam (34\%) and 21 completed secondary education with the leaving exam (39.6\%); 11 parents $(20.8 \%)$ completed university education. 2 parents of children without MD completed elementary education (3.4\%), 14 parents completed secondary education without the leaving exam (23.7\%), 26 completed secondary education with the leaving exam (44.1\%), 2 parents have completed higher specialized education (3.4\%), 11 university education $(18.6 \%)$ and 4 parents did not answer the given question (6.8\%). Over the last $0-5$ years, 12 parents of children with MD (22.6\%) were actively employed, over the last 6-10 years the number was 11 parents of children with MD (20.8\%), over the last $11-15$ years 5 parents $(9.4 \%)$, over the last $16-20$ years 8 parents $(15.1 \%)$ and over the last 21 years and more, 17 parents of children with MD (32.1\%) were employed. Of these, 23 parents are still employed (43.4\%), 4 work part-time (7.6\%), 16 parents are unemployed (30.1\%) and 10 parents stated a different alternative, which they did not further specify (18.9\%). Over the past $0-5$ years, 16 parents of children without MD were actively employed (27.1\%), over the last 6-10 years it was 14 parents (23.7\%), over the last $11-15$ years it was 11 parents $(18.65 \%)$, over the last $16-20$ years it was also 11 parents $(18.65 \%)$ and over the last 21 years and more, 5 parents of children without MD (8.5\%) had employment. 2 parents (3.4\%) did not answer the given question. 41 parents (69.4\%) are still employed, 4 parents work part-time $(6.8 \%), 9$ parents are unemployed $(15.3 \%), 4$ stated a different alternative which they did not specify further $(6.8 \%)$ and 1 parent $(1.7 \%)$ did not answer the question.

11 parents $(20.7 \%)$ take care only of the child with MD, 26 parents (49.1\%) take care of two children, out of whom 1 has MD, 9 parents (17\%) take care of three children, out of whom 1 has MD, 2 parents $(3.8 \%)$ take care of four children, out of whom 1 child has MD, and 1 parent (1.9\%) takes care of five children, out of whom 1 has MD. 4 parents (7.5\%) did not answer this question. None of the parents take care of more than 1 child with MD. Of these, 18 parents (34\%) stay at home with the children. 27 parents $(51 \%)$ do not stay at home with the children, 4 parents $(7.5 \%)$ stated a different alternative: "I am employed." "Yes and no, in the morning special supervision." "Yes, at the weekends and on holidays." "Besides a part-time job." 4 parents (7.5\%) did not answer this question.

9 parents $(15.3 \%)$ of children without MD take care only of one child, 28 parents $(47.5 \%)$ take care of two children, 10 parents $(16.9 \%)$ take care of three children and 1 parent $(1.7 \%)$ takes care of five children. 11 parents $(18.6 \%)$ did 
not answer the question. 18 parents (30.5\%) stay at home with the children, 37 parents $(62.7 \%)$ do not stay at home with the children, and 2 parents $(3.4 \%)$ stated a different alternative: "Part-time job, otherwise am at home with the child." "I work in at a hairdresser's 4 hours a day." 2 parents (3.4\%) did not answer the question.

As stated before, 53 parents take care of a child with MD. Of these, 3 parents (5.7\%) take care of a child under 3 years of age, 5 parents $(9.4 \%)$ of a child under 6 years of age, 8 parents $(15.1 \%)$ of a child under 10 years of age, 7 parents $(13.2 \%)$ of a child under 12 years of age, 7 parents $(13.2 \%)$ of a child under 15 years of age, and 14 parents $(26.4 \%)$ of a child over 15 years of age. 9 parents $(17 \%)$ did not answer the question.

47 children with MD attend a day care center (92.1\%), 1 child with MD attends a week care center (2\%), 2 stay at home (3.9\%), 1 parent (2\%) stated a different alternative: "within school schedule", and 2 parents did not answer the question. The second part of the questionnaire focused on psychosocial and economical characteristics and perspectives. The respondents were first supposed to state how the following factors have changed over the period of their care for the child both with MD and without MD: the extent of spiritualism, altruism, tolerance, peace and balance, faith, life optimism, humbleness, ability to relax in free time and care for oneself. The results of the particular categories of focus are listed in percent in the table 1.

Table 1

Values perceived positively by parents taking care of a child with MD

\begin{tabular}{|l|c|c|c|c|}
\hline \multicolumn{1}{|c|}{ Area of focus (\%) } & Has risen & $\begin{array}{c}\text { Has } \\
\text { stayed the } \\
\text { same }\end{array}$ & Has fallen & $\begin{array}{c}\text { Did not } \\
\text { answer }\end{array}$ \\
\hline $\begin{array}{l}\text { extent of spiritualism (experiencing } \\
\text { faith and spiritualism) }\end{array}$ & 24.5 & 54.7 & 5.7 & $\mathbf{1 5 . 1}$ \\
\hline $\begin{array}{l}\text { extent of altruism (readiness to } \\
\text { help others) }\end{array}$ & 39.6 & 52.8 & 1.9 & 5.7 \\
\hline extent of tolerance towards others & $\mathbf{4 3 . 4}$ & 52.8 & 1.9 & 1.9 \\
\hline extent of peace and balance & 11.4 & 52.8 & 35.8 & 0 \\
\hline extent of faith in human solidarity & 17 & 47.1 & 30.2 & 5.7 \\
\hline extent of life optimism & 13.2 & $\mathbf{5 8 . 5}$ & 26.4 & 1.9 \\
\hline $\begin{array}{l}\text { extent of humbleness towards what } \\
\text { life brings }\end{array}$ & $\mathbf{4 3 . 4}$ & 43.4 & 11.3 & 1.9 \\
\hline $\begin{array}{l}\text { extent of ability to relax in free } \\
\text { time }\end{array}$ & 13.2 & 30.2 & $\mathbf{5 2 . 8}$ & 3.8 \\
\hline extent of care for oneself & 9.5 & 35.8 & $\mathbf{5 2 . 8}$ & 1.9 \\
\hline
\end{tabular}

By briefly summarising the answers received from parents taking care of a child with MD we will find that the highest increase in positive values stated by the respondents occurred in the extent of tolerance towards others and the extent of humbleness towards what life brings. In both cases, the number was $43.4 \%$ of 
respondents who provided an answer. On the other hand, the value that fell the most in respondents was the extent of ability to relax in free time and the extent of care for oneself - in both cases it was $52.8 \%$.

In parents taking care of a child without $\mathrm{MD}$, the highest increase in positive values occurred in the extent of altruism, i.e. in the readiness to help others (42.4\%). The biggest decrease occurred in the area of extent of care for oneself, namely $47.5 \%$.

If we compare the results of both surveyed groups, we can notice that both groups recorded the biggest decrease in the area of extent of care for oneself. There are no significant differences in the increased values either. Parents taking care of a child with MD recorded the highest increase in the area of extent of tolerance towards others. In parents taking care of a child without MD, this was the second most increased value recorded.

In the next part of the research questionnaire, we were interested in the question after how many years of caring for a child with or without MD the stated conditions occurred and if these conditions still prevail.

In parents taking care of a child with MD, the predominating state was the loss of ability to enjoy free time (24.5\%). The most often stated condition, which does not last any more, was the loss of the feeling of having things under control and massive onset of depression (28.3\%).

Parents taking care of a child without MD most often suffer from feeling of exhaustion (11.9\%); loss of the ability to feel joy was most often given as the condition that does not last any longer $(23.7 \%)$.

In the next part of the research, we attempted to find out whether any of the following changes occurred as a result of long-term care for a child with or without MD: increase in isolation of tending parents resulting from long-term care of a child, worsening of health condition, worsening of the economic situation, worsening of relationships among family members, and the worsening of social life of the tending family.

As far as positive consequences are concerned, our aim was to establish whether the parents feel enriched by the care of the child. Parents taking care of a child with MD felt, according to the results, in most cases enriched by the given situation (33), out of which 10 parents stated the answer as yes and 23 rather yes. However, quite a large group was also formed by parents answering negatively. 9 parents taking care of a child with MD do not feel enriched by the given situation. In parents taking care of a child without MD, positive answers were significantly predominant. 34 parents feel enriched by the situation and 16 parents feel rather enriched.

The next part of the research focused on the division of care for the child among individual family members, the parents' opinion of the state and social support for parents taking care of a child with or without MD, and the biggest gain and loss of the parents resulting from the care of a child with and without MD. 
Regarding the question of who takes care of the child the most, the significantly prevailing answer in both groups was women (32 women taking care of a child with MD and 33 women taking care of a child without MD). In neither, the parents taking care of a child with MD nor the parents taking care of a child without MD does the male parent take care of the child more than the mother. Siblings of both the child with MD and the child without MD are usually involved in the care child and thus help their parents. This was stated by 25 parents taking care of a child with MD and by 33 parents of a child without MD. In both cases, the extended family mostly tries to help with the care. In families taking care of a child with MD, 16 parents answered yes and 12 rather yes. 20 parents taking care of a child without MD answered yes and 18 rather yes.

As regards the evaluation of financial support from the state, both groups of respondents answered negatively. 19 parents taking care of a child with MD believe that there is no prevailing readiness to financially support child care in the country, 17 parents chose the answer rather not. 22 parents taking care of children without MD believe that the readiness to financially support child care most probably does not prevail, and 12 parents believe that this readiness does not prevail at all.

On the question of respect and recognition of the society experienced by the tending persons, 13 parents taking care of a child with MD stated that they do not experience it, 16 parents rather not experience respect and recognition. In parents taking care of a child without MD, the situation is similar. 27 parents do rather not experience respect and recognition in society.

The next part of the research was focused on the area or work competencies. First, we aimed to establish after how many years the parents believe that irreversible loss of work competencies occurs in the tending persons. In parents taking care of a child with MD, the opinions prevailed that irreversible loss of work competencies occurs in the tending person after 5 years (15 parents) and 10 years (11 parents). In parents taking care of a child without $\mathrm{MD}$, the opinions prevailed that it occurs after 10 years (26 parents). 11 parents taking care of a child with MD believe that returning to their original profession is absolutely impossible. A lot of the parents expressed the feeling of social isolation resulting from unemployment. 9 parents taking care of a child with MD stated that they would be willing to do work inferior to their education level. This willingness to do work that is inferior to one's education was also stated by 6 parents taking care of a child without MD. On the other hand, 5 parents from both groups stated that they would not be willing to do any inferior work (the second most frequent group of answers). 6 parents taking care of a child with MD stated that unemployment resulting from the care for a child suits them. In both groups, however, the prevailing answers were that unemployment resulting from long-term care of a child does not suit the parents ( 9 parents taking care of a child with MD, 7 parents taking care of a child without MD). 


\section{Evaluation of the questionnaire research using the SEIQoL method}

The standardized questionnaire SEIQoL focuses on the respondents' life goals and their fulfilment. The respondent is supposed to state 5 life goals, and for each of them state its importance and their satisfaction with the given stimulus. The total sum of the given percentage of importance for all 5 goals of the respondent should be $100 \%$ (or less). Satisfaction with particular goals was supposed to be expressed on a scale of 0 to $100 \%$ without the condition that the total sum must be $100 \%$. The text below represents the particular life goals stated by parents taking care of a child with MD and by parents taking care of a child without MD.

Table 2

First life goal (SEIQoL)

\begin{tabular}{|c|c|}
\hline \multicolumn{2}{|c|}{ First life goal } \\
\hline $\begin{array}{l}\text { Parents taking care of a child with MD } \\
\qquad 32(60.4 \%) \text { parents }\end{array}$ & $\begin{array}{c}\text { Parents taking care of a child without } \\
\text { MD } \\
39(66.1 \%) \text { parents }\end{array}$ \\
\hline $\begin{array}{l}\text { - children, their upbringing and } \\
\text { preparation for the future (11 parents, } \\
\text { i.e. } 20.8 \% \text { ouf of the total number of } \\
\text { parents taking care of a child with MD), } \\
\text { - } \text { health of the children and all family } \\
\text { members }-4 \text { parents }(7.5 \%) \text {, } \\
\text { - } \text { satisfied family and care for the family- } \\
6 \text { parents }(11.3 \%) \text {, } \\
\text { - } \text { marriage and partnership - } 3 \text { parents } \\
\text { (5.7\%), } \\
\text { - securing the children and the family - } 3 \\
\text { parents }(5.7 \%) \text {, } \\
\text { - other }-5 \text { parents }(9.4 \%) \text {. }\end{array}$ & $\begin{array}{l}\text { - children and their upbringing (12 } \\
\text { parents, i.e. } 20.3 \% \text { out of the total } \\
\text { number of parents taking care of a child } \\
\text { without MD), } \\
\text { - } \\
\text { health of the children and all family } \\
\text { members }-11 \text { parents }(18.6 \%) \text {, } \\
\text { - } \text { family and their satisfaction }-7 \text { parents } \\
\text { (11.9\%), } \\
\text { - } \text { faith }-3 \text { parents }(5.1 \%), \\
\text { - other }-6 \text { parents }(10.2 \%) \text {. }\end{array}$ \\
\hline
\end{tabular}

From the abovestated, it is obvious that both parents of children with MD and of children without MD have similar life goals. In the majority of cases these are children, their upbringing, health and satisfaction of the family.

If we were to somehow summarize the results of the SEIQoL questionnaire, we can say that the stated life goals of parents taking care of a child with MD and of parents taking care of a child without MD do not significantly differ. Both groups listed among their first life goals: children, their upbringing and preparation for the future, health of the children and of all family members, and family and their satisfaction; 3 parents taking care of a child with MD gave as their first life goal marriage and partnership; and 3 parents taking care of a child without MD gave as their first life goal faith. The second life goal was most frequently represented by: children and their upbringing, health, family, marriage, employment and financial security. Employment (work), family, 
friends, free time and interests were in both groups usually listed as their third life goal. In the fourth and fifth life goals, we could already observe the onset of differences between parents taking care of a child with MD and the parents taking care of a child without MD, and we could also see considerable variance in the answers. Goals connected with satisfaction and finances occurred more often.

\section{Conclusions and discussion of the research results}

The aim of this research was to compare the quality of life of parents taking care of a child with MD and the quality of life of parents taking care of a child without MD. 53 parents taking care of a child with MD and 59 parents taking care of a child without MD took part in the research.

When we summarize the results of the research, we must state that the quality of life of parents taking care of a child with MD and the quality of life of parents taking care of a child without MD do not, in general, essentially differ. We have reached this conclusion based on the particular answers provided to the given items in the research questionnaire by both groups of parents, i.e. parents taking care of a child with MD and parents taking care of a child without MD.

For us, this was a rather surprising finding, which may point to the fact that parents taking care of a child with MD receive more and more attention. One of the causes might be a constantly developing system of social, educational and health services in the Czech Republic, which the parents taking care of a child with MD can use.

On the other hand, the research results also pointed out a range of problematic areas. Let us mention e.g. the area of free time, parents's relaxation, preventing tiredness and the area of parents' care for oneselves or their negative perception of the society's respect and recognition for parents taking care of such a child. A large problematic area is also the financial support for child care from the state. If we compare the established problematic areas for example with the results of the research "Quality of life of families taking care of a member with a severe health disability", which was conducted in the Czech Republic in 2010, we will find that also in that research, the items such as loss of parents' ability to enjoy free time or feelings of exhaustion occurred in the tending persons quite often - in $34.1 \%$ and $43.35 \%$ of respondents (Michalík, 2010, accessible at http://www.sancedetem.cz/cs/hledam-pomoc/deti-se-zdravotnim-

postizenim.shtml, [cit. 19. 1. 2014]) The results of Reseach into stressful and resilient factors and tendencies in persons taking care of a family member with a health disability in the area of the capital city Prague show that the most common condition that prevails in the tending persons is the loss of personal life perspectives $(35.2 \%)$. It is important to point out that $33.3 \%$ of respondents experience feeling of exhaustion and $29.8 \%$ complain of the loss of ability to enjoy free time (Michalík, Valenta in Titzl, 2008). 
Although the research did not prove that the quality of life of parents differs significantly depending on the fact whether or not they take care of a child with a mental disability, the research results do most certainly call for dealing with the abovementioned problematic areas. This concerns especially the area of free time of parents taking care of a child with MD and preventing their feeling of exhaustion, the area of parents' awareness of the possible solutions to the given situation and of using the services offered in the Czech Republic and using, for example, the services of volunteers.

\section{References}

1. Dušková, L., Svobodová, L. (2006). Co to je kvalita života. Dvořáková, Z. a kol. Svět práce a kvalita života: vliv změn světa práce na kvalitu života: výzkumný projekt v rámci programu Moderní společnost a její proměny. Praha: Výzkumný ústav bezpečnosti práce, p. $18-21$.

2. Dvořáková, Z., Dušková, L. (2006). Kvalita života a sociologie. Dvořáková, Z. et al. Svět práce a kvalita života: vliv změn světa práce na kvalitu života: výzkumný projekt v rámci programu Moderni společnost a její proměny. Praha: Výzkumný ústav bezpečnosti práce, p. 23-24.

3. Kozáková, Z. (2013). Special Education of Persons with Mental Disabilities. Olomouc: Univerzita Palackého v Olomouci, $117 \mathrm{p}$.

4. Křrivohlavý, J. (2002). Psychologie nemoci. Praha: Grada Publishing, 198 p.

5. Křivohlavý, J. (2001). Psychologie zdraví. Praha: Portál, 279 p.

6. Michalík, J. [online]. Děti se zdravotním postižením [19. 1. 2014]. Dostupné na World Wide Web: <http://www.sancedetem.cz/cs/hledam-pomoc/deti-se-zdravotnimpostizenim.shtml>

7. Michalík, J., Valent, M. (2008). Výzkum stresujících a resilientních faktorů a tendencí osob pečujících o člena rodiny se zdravotním postižením na území hlavního města Prahy. Titzl, B., et al. Speciální pedagogika: časopis pro teorii a speciální praxi speciálni pedagogiky. Praha: Univerzita Karlova, y. 18, vol. 2, p. 149-169.

8. Prokešová, M. (2008). Volný čas z hlediska kvality života. Ostrava: Ostravská univerzita v Ostravě, $68 \mathrm{p}$.

9. Vad'urová, H., Mühlpachr, P. (2005). Kvalita života: teoretická a metodologická východiska. Brno: Masarykova univerzita v Brně, 143 p.

$\begin{array}{ll}\text { Mgr. Zdeňka Kozáková, } & \text { Institute of Special Education Studies, Faculty of } \\ \text { Ph.D., DiS. } & \text { Education } \\ & \text { Palacky University in Olomouc Žižkovo náměstí 5, } 77140 \\ & \text { Olomouc } \\ & \text { Tel.: +420 } 585635317 \\ & \text { Email: Zdenka.Kozakova@upol.cz }\end{array}$

